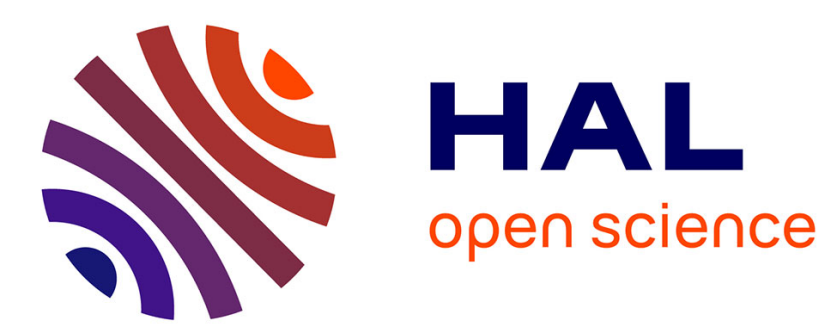

\title{
Bioleaching of an organic-rich polymetallic concentrate using stirred-tank technology
}

Pauline Spolaore, Catherine Joulian, Jérôme Gouin, Thierry Augé, Dominique Morin, Patrick d'Hugues, Andres E Ibañez

\section{- To cite this version:}

Pauline Spolaore, Catherine Joulian, Jérôme Gouin, Thierry Augé, Dominique Morin, et al.. Bioleaching of an organic-rich polymetallic concentrate using stirred-tank technology. Hydrometallurgy, 2009, 99 (3-4), p. 137-143. 10.1016/j.hydromet.2009.07.011 . hal-00512815

\section{HAL Id: hal-00512815 https: / hal-brgm.archives-ouvertes.fr/hal-00512815}

Submitted on 30 Sep 2010

HAL is a multi-disciplinary open access archive for the deposit and dissemination of scientific research documents, whether they are published or not. The documents may come from teaching and research institutions in France or abroad, or from public or private research centers.
L'archive ouverte pluridisciplinaire HAL, est destinée au dépôt et à la diffusion de documents scientifiques de niveau recherche, publiés ou non, émanant des établissements d'enseignement et de recherche français ou étrangers, des laboratoires publics ou privés. 


\title{
Bioleaching of an organic-rich polymetallic concentrate using the stirred-tank technology
}

P. Spolaore ${ }^{1 *}$, C. Joulian ${ }^{1}$, J. Gouin ${ }^{2}$, A. Ibáñez ${ }^{3}$, T. Augé ${ }^{2}$ D. Morin ${ }^{1}$ and P. d'Hugues ${ }^{1}$

${ }^{1}$ BRGM, EPI/ECO, 3 Av. C. Guillemin, 45060 Orléans cedex 2, France

${ }^{2}$ BRGM, REM/MESY, 3 Av. C. Guillemin, 45060 Orléans cedex 2, France

${ }^{3}$ Técnicas Reunidas, Hydrometallurgy \& Electrochemistry, Sierra Nevada 16, 28830 San

Fernando de Henares, Madrid, Spain

${ }^{*}$ Corresponding author. E-mail address: p.spolaore@brgm.fr (P. Spolaore)

\begin{abstract}
The bioleaching of a concentrate produced from a black shale ore in an industrial operation in Poland was assessed. Following preliminary batch culture tests, processing in continuous conditions was tested to determine the main specifications for the application of the stirred-tank technology to this organic-rich polymetallic concentrate.

The experimental work was carried out in a laboratory-scale unit consisting of 3 stirred tanks (50L or 20L) using an acidophilic and moderate thermophilic bacterial population $\left(42^{\circ} \mathrm{C}\right)$. Different configurations of the unit and key operating parameters were tested (nutrient medium composition, solids concentration, agitation and aeration rates). The analysis of both bacterial community structure and mineralogical characteristics of the concentrate and the bioleach residues were implemented in order to better understand the chemical and biochemical reactions occurring in the system. Using the data produced during the continuous operation, downstream processing assessment for both copper and silver recovery was also carried out.
\end{abstract}


The best copper recovery obtained in the continuous operation was $92 \%$ and a hot brine leaching of the bioleach residue (PLINT process) allowed to recover $92 \%$ of the silver. Copper and silver recoveries seemed to be limited by incomplete chalcopyrite dissolution. A preliminary techno-economic evaluation of the concentrate bioprocessing including bioleaching, copper and silver recoveries demonstrated the potential economic feasibility. Recovery of silver plays an important role in the economy of the process. This study presents promising values to further investigate the bioprocessing option.

Key words: bioleaching, black shale, copper, silver, stirred-tank reactor 


\section{Introduction}

European black shale ore deposits, in particular the Kupferschiefer, contain considerable reserves of base and highly valuable rare and precious metals (including $\mathrm{Cu}, \mathrm{Ni}, \mathrm{Zn}, \mathrm{Pb}$, $\mathrm{Ag}, \mathrm{Au}, \mathrm{Pt}, \mathrm{Pd}$ ) of which Europe is the main consumer. The black shale ores are typically polymetallic ores with a variable proportion of sulphidic components and an organic carbon content that exceed at least $0.5 \%$. The metal-bearing compounds are dispersed as small-size particles and the valuable metals may be trapped in organic matter in the ore or in slimes. Two major difficulties restrict the exploitation of the black shale ores. The first is the low efficiency of the conventional technical means for recovering valuable metals, from mining extraction to metallurgical processing. The second is the environmental impact of the application of the conventional techniques (d'Hugues et al., 2008a).

Thanks to the extensive research carried out during the last 30 years, the potential of biooxidation and bioleaching processes is well recognized. The treatment of some minerals (sulphides, oxides) and the recovery of metals such as copper, gold and cobalt through biohydrometallurgical technologies are now well established (Dreisinger, 2006; Rawilings et al., 2003; Watling, 2006). However, it is not known if organic-rich black shale ores present peculiar problems that could severely impact bioprocessing using established biological systems and engineering protocols. The question of whether or not bioleaching could be a reasonable technical option for recovery of metals from these ores was addressed during Bioshale project (http://bioshale.brgm.fr/). The main goal of this project was to define an innovative biotechnological process for the eco-efficient exploitation of black shale ores for metals production (d'Hugues et al., 2008a).

In the frame of Bioshale, one of the case studies concerned a carbonate-rich copper concentrate produced from a black shale ore in an industrial concentrator located in 
Poland. This concentrate is a polymineral (copper sulphides are mainly bornite, chalcocite and chalcopyrite) and polymetallic $(\mathrm{Cu}, \mathrm{Ag})$ resource. Bioleaching of the concentrate after non-oxidative acid pre-treatment for carbonate decomposition was selected as an interesting bioprocess option (d'Hugues et al., 2007). The bioleaching option is not yet of direct interest in the context of the current industrial process. Nevertheless, it could become an interesting option in the case of capacity shortage in the smelter, or production of a "dirty concentrate" (e.g. presence of arsenic). From a more academic point of view, it is a relevant case study for investigating the development of bioleaching technologies for copper recovery that can be applied to a multi-elements $(\mathrm{Cu}$, $\mathrm{Ag}$ ) and polymineral concentrate, containing chalcopyrite. Research and development for hydrometallurgical alternatives to traditional pyrometallurgy of copper resources has intensified recently as world demand for copper is steadily growing. More than $20 \%$ of copper is now produced by hydrometallurgy. However, efficiency of leaching strongly depends upon the nature of the copper sulphides. Chalcopyrite, is both the most abundant copper mineral in nature, and the most highly refractory under hydrometallurgical conditions. It represents a key target for the industry. The recovery of valuable byproducts (here silver) is also known to be one of the reasons for pursuing alternatives to conventional processing. Even if copper smelters are efficient at recovery of gold, silver and PGM's, they often pay poorly and with much delay for these elements (Dreisinger, 2006; Watling, 2006).

The technical objective of the work was to determine the main specifications for the application of the stirred-tank technology to the polish concentrate. This paper more specifically reports the continuous bioleach testing in a laboratory-scale unit carried out after preliminary batch tests. The following conditions were investigated: solids concentration in the feed, configuration of the unit (number and size of the reactors), 
nutrient medium composition and agitation-aeration rates. Another objective of the work was to better understand the chemical and biochemical reactions occurring in the system. Therefore, bacterial population composition and mineralogical modifications were specifically monitored during the tests. The data collected during this experimental testwork, combined with information concerning downstream processing for both copper and silver recovery, were finally used to establish a preliminary techno-economic evaluation of the process.

\section{Methods and material studied}

\subsection{Bioshale-BRGM bacterial consortium}

The culture used in this study originated from a mixture of two consortia cultured for many years on both a cobaltiferous pyrite and a copper concentrate (d'Hugues et al., 2003; Morin and d'Hugues, 2007). It was subcultured several times in batch mode on the polish copper concentrate before being used as an inoculum in the continuous test. The predominant organisms in the culture were affiliated to the genera Leptospirillum, Acidithiobacillus and Sulfobacillus.

\subsection{Bacterial community structure}

The structure of the bioleaching population was investigated in the inoculum used to start the continuous operation and during the campaign, when the unit $(3 \times 20 \mathrm{~L}$ reactors $)$ was running with $15 \%$ solids concentration (configuration 2). $0.5 \mathrm{~mL}$ of homogenous bioleaching pulp was centrifuged and the pellet was washed twice by re-suspension in $100 \mathrm{mM}$ citrate ( $\mathrm{pH}$ 4). DNA was extracted from the washed pellets with the FastDNA Spin Kit for Soil (Bio101) using a modified procedure that included a treatment with 5.5 M guanidine thiocyanate recommended by the manufacturer for high organic matter content samples and two steps of mechanical lyses for better cell disruption. Single- 
stranded PCR products of same length but different sequence were separated based on their sequence by the structural analysis technique SSCP, as described elsewhere (d'Hugues et al., 2008b).

\subsection{Sulphide material}

The sulphide material was a copper concentrate originating from a black shale ore and produced by a polish concentrator. The main characteristics of the sample were as follows: $\mathrm{Cu} 16.1 \%, \mathrm{Ag} 1010 \mathrm{mg} / \mathrm{kg}, \mathrm{Fe} 7.1 \%$, sulphur as sulphide $11.5 \%$, Cmin 2.1\%, Corg 8.2\%, particle size (cumulative passing 80\%) $40 \mu \mathrm{m}$. Copper sulphides composition of this material was determined by mineralogical analysis.

\subsection{Mineralogical analysis}

In order to determine quantitatively the different proportions of each mineral phase in the concentrate and in the bioleach residues, the following protocol was used. Bromoform (density 2.8) densimetric separation was performed to separate heavy minerals from barren minerals and organic matter. Then, the concentrate of heavy minerals was compacted at high pressure using an anvil and the "compact disk" resulting from the process was polished. Finally, a CAMECA SX50 electron probe microanalyser (EPMA) equipped with 5 spectrometers (WDS technique) was used to determine the proportions of each mineral phase in a similar way as the counting point technique.

\subsection{Nutritive media}

The basic nutrient medium was the 0Km medium (Battaglia et al., 1994). Its standard composition was the following: $\left(\mathrm{NH}_{4}\right)_{2} \mathrm{SO}_{4}, 3.70$ g.L ${ }^{-1} ; \mathrm{H}_{3} \mathrm{PO}_{4}, 0.80$ g.L $\mathrm{L}^{-1} ; \mathrm{MgSO}_{4} \cdot 7 \mathrm{H}_{2} \mathrm{O}$, 0.52 g. $\mathrm{L}^{-1} ; \mathrm{KOH}, 0.48$ g. $\mathrm{L}^{-1}$. A dilution of the medium by a factor 3 was one of the parameter tested in the continuous operation.

\subsection{Laboratory-scale batch tests}


Batch experiments at $10 \%$ solids were carried out in $2 \mathrm{~L}$ laboratory-scale glass reactors thermostated at $42^{\circ} \mathrm{C}$. Air $\left(120 \mathrm{~L} . \mathrm{h}^{-1}\right)$ enriched with $\mathrm{CO}_{2}(1 \%)$ was injected beneath a turbine (rotation speed at $400 \mathrm{rpm}$ ) at the bottom of the reactor via a stainless steel pipe.

\subsection{The laboratory-scale continuous unit}

The continuous bioleaching operation was carried out in a laboratory-scale unit equipped of 3 stirred reactors (R1, R2, R3).

Two configurations were tested:

- Configuration 1: three tanks, one of 50L (R1) followed by two of 20L operating capacity (R2, R3),

- Configuration 2: three tanks, all of 20L operating capacity (R1, R2 and R3).

The tanks were all made from 304-L stainless-steel and had a height/diameter ratio equal to 1 . The reactors were arranged in cascade so that the pulp passes from one tank to the next one by overflowing. Air enriched with $\mathrm{CO}_{2}(1 \%)$ was injected beneath the turbine at the bottom of the tank. The top of the reactors were connected to a condenser system to prevent excessive evaporation. The same mixing system (BROGIM® - BRGM/MRM) was mounted in all tanks on a rotating shaft.

The feed was made up of a high density pulp of concentrate flow (30\% wt.wt ${ }^{-1}$ in water) and a concentrated nutritive medium flow. The two feed flows were pumped separately into the first tank in a ratio corresponding to the solids ratio required for the feeding pulp. The temperature of culture was maintained constant at $42^{\circ} \mathrm{C}$ by circulating cold water through an internal stainless-steel coil for cooling and by an external electric ribbon for heating.

In the first tank, the $\mathrm{pH}$ was regulated around 1.5 by adding $\mathrm{H}_{2} \mathrm{SO}_{4}(20 \% \mathrm{v} / \mathrm{v})$ in the pulp. $\mathrm{pH}$ regulation was not necessary in the other tanks. The main operating conditions in the pilot are presented in table 1. 


\subsection{Analytical techniques}

For the batch and continuous experiments, electrochemical potential and $\mathrm{pH}$ were measured directly in the pulp. Copper and total iron concentrations were measured by atomic absorption spectroscopy (Varian SpectrAA-300) in the supernatant fraction from $0.45 \mu \mathrm{m}$ filtered culture samples.

When the continuous unit was operating at steady state, samples were collected from the overflowing pulp at the exit of the reactors and from the initial pulp feed. Samples of pulp were first filtered with a Büchner funnel. The filtered solid material was then rinsed with a sulphuric acid solution at $\mathrm{pH} 1.5$ and dried. Copper, iron and other chemical elements contained in the solid and liquid phases were analysed by atomic absorption.

\subsection{Techno-economic study}

A preliminary techno-economic evaluation of the concentrate bioprocessing including bioleaching, copper recovery by means of hydrometallurgical route and silver recovery from the bioleach residue was established. Main information was taken from research activities performed on bioleaching of the concentrate and downstream treatment on liquors and bioleach residue. Data from literature on conventional technologies (as EW, SX, etc...) were also used.

\section{Results and analyses}

\subsection{Preliminary batch tests}

When treated in batch, a non-oxidative acid treatment $\left(170 \mathrm{~g} \mathrm{H}_{2} \mathrm{SO}_{4} / \mathrm{kg}\right)$ of the copper concentrate was necessary in order to dissolve most of the carbonates prior to the bioleaching step (more than $90 \%$ of the inorganic carbon was solubilised by the treatment, data not shown). This acidification aimed at avoiding any inhibition of the bacterial development due to $\mathrm{pH}$ increase caused by carbonates dissolution. The copper 
recovery in the bioleaching batch tests reached 95 to $97 \%$ in 6 days, and the maximal $\mathrm{Cu}$ leaching rate was evaluated at $255 \pm 11 \mathrm{mg} /(\text { L.h })^{-1}$ (Figure 1). This showed that the polish concentrate was amenable to bioleaching using the Bioshale-BRGM acidophilic and moderate thermophilic consortium $\left(42^{\circ} \mathrm{C}\right) .80 \%$ of silver could then be recovered from the bioleach residue. Based on these promising results with pre-treated material at $10 \%$ solids concentration, bioprocessing in continuous conditions was tested.

\subsection{Continuous bioleaching tests}

$10 \%$ solids concentration feed (configuration 1, table 1)

In continuous mode, it was decided to combine acidification and bioleaching in the first stage of the unit. The stabilisation of the bacterial culture and of the bioleaching performances was observed very quickly after the start. The copper dissolution (Figure 2) was estimated at $91 \%$ after 6.5 days in a $90 \mathrm{~L}$ operating volume. Most of the leaching occurred in the first tank as copper dissolution already reached $77 \%$ after 3.3 days of residence time. The first $10 \%$ solids continuous test showed the technical feasibility of the combined non-oxidative acid treatment/bioleaching process.

15\% solids concentration feed (configuration 2a, table 1)

The solids concentration was then increased to $15 \%$ to be closer to the industrial practice and have more economically favourable conditions. A new configuration of the unit, of smaller total volume ( $3 \times 20 \mathrm{~L}$ reactors), was also assessed in order to reach a better distribution of the oxidation in between the primary reactor and the following ones. Furthermore, taking into account the relatively low sulphides content of the concentrate and the consequent limited oxygen requirements, aeration rates were reduced in all reactors as compared to configuration 1 (Table 1). Again, the continuous process reached stability very quickly. The dissolution of copper was better distributed even though the 
major part (68\%) was still occurring in the first tank (Figure 2). $90 \%$ copper recovery was achieved in a 6.5 days residence time, and in a $60 \mathrm{~L}$ operating volume.

\section{Influence of nutrient medium and aeration/agitation rates}

The next objective of the study was to test some key operating parameters. A global dilution of the nutrient medium by a factor 3 was tested. There was no influence of this change on the overall copper dissolution efficiency (results not shown). The limitation of the bioleaching efficiency to $90 \%$ was suspected to be due to a limited dissolution of chalcopyrite. Lowering redox potential is known to bring favourable conditions for chalcopyrite dissolution (Pinches et al., 2000; Third et al., 2002). For that reason, a new reduction of aeration rates in the $2^{\text {nd }}$ and $3^{\text {rd }}$ reactors was combined to a decrease of agitation speed, with the objective of limiting the oxygen transfer to the system and the oxidation rate of ferrous iron (configuration $2 b$, table 1). In order to avoid a limitation of the bacterial growth by a lack of oxygen, the reduction was not applied in the first tank. These changes had noticeable effects on the potential (Eh vs. $\mathrm{Ag} / \mathrm{AgCl}$ ) which decreased in the $2^{\text {nd }}$ reactor from $620 \mathrm{mV}$ to $385 \mathrm{mV}$ and in the $3^{\text {rd }}$ reactor from $650 \mathrm{mV}$ to $410 \mathrm{mV}$ reaching values associated with better conditions for chalcopyrite oxidation (Figure 3). Nevertheless, this resulted only in a very slight improvement of copper recovery from $90 \%$ to $92 \%$ in 6.6 days (Figure 2 ).

\subsection{Structure of the bioleaching consortium}

The predominant organisms in the Bioshale-BRGM culture used to inoculate the continuous unit, in terms of relative ratios, were: Acidithiobacillus (At.) caldus (55\%) and Leptospirillum (L.) ferriphilum BRGM1 (30\%). Two species of the genus Sulfobacillus (Sb.), Sb. thermosulfidooxidans and Sb. benefaciens sp. nov. BRGM2 (Johnson et al., 2008) represented each about $6 \%$ of the population. 
After 15 days of continuous operation (configuration 2a, table 1), L. ferriphilum was dominant (about 70\%) in R1, thus for the first two days of residence time, whereas it codominated with At. caldus over two days of residence time in R2 and R3 (Figure 4a). In these reactors, when low aeration/agitation rates were applied to the system (configuration 2b, table 1), At. caldus took rapidly advantage over L. ferriphilum, which remained at a ratio of about $20 \%$, and became the predominant microbe (about $50 \%$ ) in these reactors (Figure 4b). Whatever the aeration/agitation rates, Sb. benefaciens developed over Sb. thermosufidooxidans which was only detected at very low levels (0$4 \%$ ), although these two strains had been inoculated in similar ratios. At the end of the monitoring, the ratio of $S b$. benefaciens was similar $(18-22 \%)$ in the three reactors (Figure $4 \mathrm{~b}$ ). Contrary to lowering the agitation and aeration rates, a dilution of the nutrient medium by a factor 3 had no clear effect on the population composition (data not shown).

\subsection{Mineralogical analyses}

Mineralogical analyses were performed to evaluate the modal composition of the concentrate and of the residues obtained in all reactors at the end of the continuous operation (configuration $2 \mathrm{~b}$, table 1). Copper sulphides of the concentrate mainly consist of bornite $\left(\mathrm{Cu}_{5} \mathrm{FeS}_{4}, 36 \%\right)$, chalcocite $\left(\mathrm{Cu}_{2} \mathrm{~S}, 23 \%\right)$, chalcopyrite $\left(\mathrm{CuFeS}_{2}, 20 \%\right)$, other undetermined copper sulphides (19\%) and covellite in smaller proportions (1\%) (Figure 5). During the bioleaching process, chalcocite and bornite were almost completely dissolved in the first tank. Covellite seemed to appear in the solid phase of the first reactor but was then dissolved in the second and third tanks. Chalcopyrite was the most difficult mineral to bioleach: $35 \%$ of the initial chalcopyrite were still remaining in the final residue. This residue contained also some other copper sulphides and a very small proportion of covellite. 


\subsection{Silver recovery}

In the concentrate, silver minerals were not very abundant; silver $(1010 \mathrm{mg} / \mathrm{kg})$ was more often present as trace element into $\mathrm{Cu}$-bearing sulphides. At the end of the bioleaching process, less than $1 \%$ of the silver was measured in solution. Acanthite $\left(\mathrm{Ag}_{2} \mathrm{~S}\right)$ was found in the bioleach residue associated with silver-bearing covellite and silver-bearing polymetallic sulphate.

After optimisation of the experimental conditions of the PLINT process (hot brine leaching, Frías et al, 2002), 92\% of silver were recovered from the bioleach residue. By comparing this result with the silver recovery obtained from a chemically leached concentrate sample (ferric oxidation and desulphurisation), it was checked that factors influencing the recovery could not be directly related to the bioprocess.

\subsection{Techno-economic evaluation}

The nominal capacity covered by the study is $500000 \mathrm{t} / \mathrm{y}$ of feed material for a plant operating at full capacity on a continuous basis, totalling ca. 8000 operating hours per year. It corresponds to a production of approximately $75000 \mathrm{t} / \mathrm{y}$ of pure copper and 1300 t/y of silver cement. A block diagram presents a simplified flowsheet of the plant (Figure $6)$.

The economic analysis of the concentrate bioprocessing (Table 2) shows the potential economic feasibility of the process (about 6 years payback). Process evaluation also shows the importance of silver recovery. Recovering silver increases total investment cost by $10 \%$ and operating cost by only $2 \%$, but increases significantly the amount of sales $(+32 \%$ ) (Table 2). This is due to the high value of silver (31 $226 € /$ t, average price for the last ten years) compared to the price of copper (2000€/t, average price for the last ten years). 


\section{Discussion and conclusions}

The main objective of this work was to evaluate the technical and economical feasibility of the bioprocessing of a polish organic-rich polymetallic concentrate. Copper recovery from chalcopyrite and silver recovery from bioleached residue were both investigated. The selected process option consisted in the bioleaching of the concentrate combined with a non-oxidative acid treatment for carbonate decomposition.

The bioleachability of the concentrate was first assessed in batch tests. 95 to $97 \%$ copper recovery was obtained. The technical feasibility of the continuous treatment in stirred reactors was then demonstrated by running a laboratory scale operation at $10 \%$ solids (91\% $\mathrm{Cu}$ recovery after 6.5 days). No particular problem was raised by the presence of the organic matter in the concentrate. This first interesting result underlined the possibility to apply bioleaching stirred-tank technology to a new type of resource, the organic-rich concentrates originating from black shale ores. Copper ( $\mathrm{Ag}, \mathrm{Pb}, \mathrm{Zn})$ Kupferschiefer type of ore are probably one of the major resources worldwide, particularly in central Africa, Asia and Central Europa (I. Salpeteur, personal communication).

From the $10 \%$ solids conditions, the main specifications for a potential industrial application of this stirred-tank technology to the concentrate were determined. These specifications were then used for the preliminary economic evaluation of the process. The solids concentration feed was increased to $15 \%$ and some parameters of the process were studied (number and size of the reactors, concentration of the nutrient medium, conditions of agitation and aeration).

The increase in the solids concentration from 10 to $15 \%$ demonstrated the possibility to bioleach the same concentrate feed rate in the same residence time but in a reduced size of the unit $(90 \% \mathrm{Cu}$ recovery after 6.5 days in $60 \mathrm{~L}$ instead of $90 \mathrm{~L})$. These new operating 
conditions also allowed to obtain a better balance of the oxidation towards the bioleaching unit.

A global dilution of the medium by a factor 3 was then tested. Even if the determination of the exact nitrogen requirements is difficult to estimate (Rawlings, 2005), it is known that the $0 \mathrm{Km}$ medium is a quite rich medium, especially concerning the nitrogen source (ammonium). Excess of ammonium and/or other nutrients, by allowing iron and silver precipitation could not only promote chalcopyrite hindering and slow down the copper recovery kinetics (Cordoba et al., 2008a; Klauber, 2008; Sandström et al., 2005) but also limit silver extraction from the bioleached residue (Frías et al., 2002). Reducing the potential impact of the nutrients on precipitation phenomena should be an alternative to improve process metal recovery. However, this had no significant consequence on final copper dissolution efficiency.

It could be suspected that the final copper recovery was limited due to an incomplete chalcopyrite oxidation. Chalcopyrite represents $20 \%$ of the concentrate copper sulphides i.e. $12 \%$ of the initial copper content in the resource. There is a consensus saying that the reduction of leaching kinetics of this mineral is due to the formation of a hindering phase or passivation film, which builds up on its surface. However, there is still a debate concerning the nature of this film. Four candidates are most often proposed: metal deficient sulphides, elemental sulphur, polysulphides and jarosites (Cordoba et al., 2008a; Klauber, 2008; Rodriguez et al., 2003). From a process point of view, many authors agree on the fact that the dissolution rate of chalcopyrite is higher at redox potential of leach solution below a critical value (Hiroyoshi et al. 1997, 2000, 2001). Tshilombo et al. (2002) demonstrate that passivation of chalcopyrite occurs at low temperature within the potential range $450-600 \mathrm{mV}$ (vs. $\mathrm{Ag} / \mathrm{AgCl}$ ); Pinches et al. (2000) advise potential between $380 \mathrm{mV}$ and $480 \mathrm{mV}$ and Cordoba et al. (2008b) indicate a critical redox 
potential value of $413 \mathrm{mV}$ above which chalcopyrite dissolution slows down. As a consequence, it was decided in this work to decrease agitation/aeration rates in the two last reactors in order to meet adequate electrochemical potential conditions (Eh decreased to $380 \mathrm{mV}$ in $\mathrm{R} 2$ and $410 \mathrm{mV}$ in $\mathrm{R} 3$ ). The conditions in the first reactor were not changed in order to maintain a high oxidation rate of the other copper sulphides and a good bacterial growth. By decreasing agitation/aeration rates in the following reactors, oxygen transfer was reduced and bacterial iron oxidation efficiency became limited. The iron(III)/iron(II) ratio was modified changing the electrochemical potential which directly depends on this ratio. However, there was only a very slight improvement of $\mathrm{Cu}$ dissolution. It reached $92 \%$ recovery in a 6.6 days residence time instead of $90 \%$ in 6.5 days in the previous operating conditions (configuration 2a, table 1).

To better understand the chemical and biochemical reactions occurring at each step of the process, some complementary analyses were undertaken. Mineralogical study was one of the approaches applied. The correlation of ore mineralogy, reaction chemistry and leach residue mineralogy is quite innovative as little results have already been reported in the public domain (Watling, 2006). Chalcocite and bornite, the easiest minerals to bioleach were almost completely dissolved in the first reactor. Dissolution of both chalcocite and chalcopyrite is suggested to be a two steps process, covellite being an intermediary product (Dixon, 2000; Leahy et al., 2007; Tshilombo et al., 2002). This explains the increase of covellite quantities in the bioresidue at the beginning of the process. Covellite is then dissolved in the second and third reactors. The final residue is composed mainly of chalcopyrite comforting the previous hypothesis of incomplete oxidation of this mineral. So, the decrease in electrochemical potential in the last two reactors was not efficient to significantly improve chalcopyrite dissolution. Passivation might already have occurred in the first reactor where the potential remained high (around $580 \mathrm{mV}$ ). A 
potential improvement of the process should be to combine first, a controlled potential step with a second step at high potential values. It is also important to remember that no limitation of the copper recovery was observed in batch mode. The reasons of the performances discrepancy between batch and continuous bioleaching mode remain to be determined.

The bioleach residue also contained silver mainly in the form of acanthite $\left(\mathrm{Ag}_{2} \mathrm{~S}\right)$. During the bioleaching process, the silver which is initially present as trace element into $\mathrm{Cu}-$ bearing sulphides, is progressively released in the liquid phase. However, as free silver is unstable in low temperature aqueous conditions (Craig et al., 2002), it reacts with available solubilised anions resulting in the precipitation of acanthite. Finally, only $1 \%$ of the silver is measured in solution. The initial presence of silver in the polish concentrate (1010 mg/kg) could potentially represent favourable conditions for chalcopyrite dissolution. It has been reported that silver content above $300 \mathrm{mg} / \mathrm{kg}$ (Cancho et al., 2007) or $800 \mathrm{mg} / \mathrm{kg}$ (Yajie et al., 2007) improves dissolution of this mineral. The reason for that improvement is that the product layer formed by a mixture of sulphur and $\mathrm{Ag}_{2} \mathrm{~S}$ is porous and does not exert a barrier effect on the chalcopyrite dissolution (Cordoba et al., 2008a). However, the catalytic effect of silver is also strongly affected by the temperature (Cancho et al., 2007; Yajie et al., 2007). It seems that, in the conditions of the continuous bioleaching presented in this paper, silver presence was not sufficient to achieve total dissolution of chalcopyrite.

The bacterial community structure was the second approach studied for the better understanding of the process. This showed that the microorganims found in the process were acidophiles commonly found in bioleaching systems (d'Hugues et al., 2008b; Johnson, 1998; Okibe et al., 2003). When reactors R2 and R3 were operated at low aeration/agitation rates (configuration $2 b$ ), it was evident that $L$. ferriphilum presence was 
negatively affected by oxygen and carbon dioxide limitations. At. caldus took advantage over L. ferriphilum and became the predominant microbe. In continuous conditions, $S b$. benefaciens developed over Sb. thermosulfidooxidans which was not detected anymore in $\mathrm{R} 1$ and only at low ratios in R2 and R3 at the end of the run. This could be explained by the less efficient $\mathrm{CO}_{2}$ uptake of $S b$. thermosulfidooxidans as compared to the one of $S b$. benefaciens therefore favoured when growing in autotrophic conditions in continuous stirred tank system (Rawlings, 2005; Johnson et al., 2008).

A preliminary techno-economic evaluation of the concentrate processing including bioleaching, copper and silver recovery, was established based both on experimental data collected during the experimental campaigns and in the literature. 92\% copper and silver recoveries were considered. As already explained, $\mathrm{Cu}$ recovery seems to be limited by the incomplete dissolution of chalcopyrite. The latter could also be one of the reasons of the limitation of silver recovery. PLINT process is perhaps more efficient to recover silver from acanthite than from $\mathrm{Cu}$-bearing sulphides. With these performances, the engineering study demonstrated all the same the potential economic feasibility of the process.

Both OPEX and CAPEX were within the range of other existing processes. OPEX of Bioshale proposed process is $0.31 € / \mathrm{lb} \mathrm{Cu}$ (i.e. around US\$ $0.38 / \mathrm{lb} \mathrm{Cu}$ ). This is more elevated than the operating costs for in place and dump leaching (US\$ $0.18-0.22 / \mathrm{lb} \mathrm{Cu}$ ) but in the range of the operating costs for heap leaching (US\$ 0.34-0.60/lb Cu (du Plessis et al., 2007; Pradhan et al., 2008). It seems to be even cheaper than certain concentrate leaching (US\$ 0.49-0.77/lb Cu) or smelting (US\$ 0.45-0.65/lb Cu) (du Plessis et al., 2007).

The CAPEX could be considered as relatively high. However, it would be improved by a treatment at $20 \%$ solids concentration which should be easily implemented. Another improvement could also still be expected. Taking into account the results obtained in 
batch mode, a better copper recovery could be obtained by optimising some key operating parameters (redox potential, particle size,...).

Comparison with other technologies should also be interpreted carefully as data available are very diverse in terms of specificities of the concentrate (mineral and metal composition) or capacity of treatment of the unit for example. The present study has been conducted for a plant capacity of $500000 \mathrm{t} / \mathrm{y}$ concentrate. This capacity has been chosen equal to the actual capacity of the industrial smelter. However, this represents a greater capacity than the one of current bioleaching installations. For example, the BIOX operations treat gold concentrate flowrates between 13000 and 320000 t/y (van Aswegen et al., 2007) and the Kasese cobalt production plant is oxidizing $82000 \mathrm{t} / \mathrm{y}$ of pyrite concentrate (Morin et d'Hugues, 2007). It is worth noting that above 200000 to $250000 \mathrm{t} / \mathrm{y}$ capacity, bioleaching processes (more particularly Biocop process) tend to reach their limits of application when compared to smelting (Clark et al., 2006). A partial bioleaching treatment of the concentrate in case of a capacity shortage of the smelter could represent a better option.

Finally, this preliminary techno-economic study opens the possibility of studying the bioleaching of the polish concentrate in CSTR in greater depth. Some technical improvements of the process could still be expected and could consequently improve the economy of the process. The latter is well impacted by the silver recovery from the bioleach residue. The importance of this part of the process was clearly underlined.

\section{Acknowledgements}

This work was carried out in the frame of Bioshale (European project contract NMP2CT-2004-505710). The authors acknowledge the financial support given to this project by the European Commission under the Sixth Framework Programme for Research and 
Development. This paper is published with the permission of BRGM as scientific contribution No. 5860 .

The authors would also like to thank KGHM Polska Miedź S.A. and KGHM Cuprum which provided the samples of the organic-rich polymetallic concentrate and Laurence Poirier (BRGM) and Antoine De Las Heras (BRGM) for their technical support.

\section{References}

Battaglia, F., Morin, D., Ollivier, P., 1994. Dissolution of cobaltiferrous pyrite by Thiobacillus ferrooxidans and Thiobacillus thiooxidans - factors influencing bacterial leaching efficiency. Journal of Biotechnology 32, 11-16

Cancho, L., Blazquez, M.L., Ballester, A., Gonzalez, F., Munoz, J.A., 2007. Bioleaching of a chalcopyrite concentrate with moderate thermophilic microorganisms in a continuous reactor system. Hydrometallurgy 87, 100-111

Clark, M.E., Batty, J.D., van Buuren, C.B., Dew, D.W., Eamon, M.A., 2006. Biotechnology in minerals processing: Technological breakthroughs creating value. Hydrometallurgy 83, 3-9

Cordoba, E.M., Munoz, J.A., Blazquez, M.L., Gonzalez, F., Ballester, A., 2008a. Leaching of chalcopyrite with ferric ion. Part I: General aspects. Hydrometallurgy 93, 8187

Cordoba, E.M., Munoz, J.A., Blazquez, M.L., Gonzalez, F., Ballester, A., 2008b. Leaching of chalcopyrite with ferric ion. Part II: Effect of redox potential. Hydrometallurgy 93, 88-96

Craig, J.R., Callahan, J.E., Kimbell, J.T., Solberg, T.N., 2002. Corrosion mineralogy of an 1800 Spanish piece of eight. Canadian mineralogist 40, 585-594 
d'Hugues, P., Battaglia-Brunet, F., Clarens, M., Morin, D., 2003. Microbial diversity of various metal-sulfides bioleaching cultures grown under different operating conditions using 16S-rDNA analysis. In: Tsezos, M., Remoudaki, E., Hatzikioseyian, A. (Eds), International Biohydrometallurgy Symposium IBS 2003, Athens, Hellas. pp 1313-1324 d'Hugues, P., Norris, P.R., Johnson, B., Grotowski, A., Chmielewski, T., Luszczkiewicz, A., Sadowski, Z., Sklodowska, A., Farbiszewska, T., 2007. Presentation of the FP6 European project Bioshale: Exploitation of black shale ores using biotechnologies Polish case studies. Physicochemical problems of mineral processing 41, 373-385 d'Hugues, P., Norris, P.R., Hallberg, K.B., Sánchez, F., Langwaldt, J., Grotowski, A., Chmielewski, T., Groudev, S., Bioshale consortium, 2008a. Bioshale FP6 European project: exploiting black shale ores using biotechnologies? Minerals Engineering 21, 111120

d'Hugues, P., Joulian, C., Spolaore, P., Michel, C., Garrido, F., Morin, D., 2008b. Continuous bioleaching of a cobaltiferous pyrite in stirred reactors: population dynamics and EPS production vs. bioleaching performances. Hydrometallurgy 94, 34-41

du Plessis C.A., Batty, J.D., Dew, D.W., 2007. Commercial applications of thermophile bioleaching. In: Rawlings, D.E., Johnson, D.B., (Eds.), Biomining. Springer, Heidelberg, pp. $57-80$

Dixon, D.G., 2000. Analysis of heat conservation during copper sulphide heap leaching. Hydrometallurgy 58 (1), 27-41

Dreisinger, D., 2006. Copper leaching from primary sulfides: Options for biological and chemical extraction of copper. Hydrometallurgy 83, 10-20

Frías, C., Díaz, G., Ocaña, N., Lozano, J.I., 2002. Silver, gold and lead recovery from bioleaching residues using the PLINT process. Minerals Engineering 15 (11), 877-878. 
Hiroyoshi, N., Hirota, M., Hirajima, T., Tsunekawa, M., 1997. A case of ferrous sulfate addition enhancing chalcopyrite leaching. Hydrometallurgy 47, 37-45

Hiroyoshi, N., Hirota, M., Hirajima, T., Tsunekawa, M., 2000. A model for ferrouspromoted chalcopyrite leaching. Hydrometallurgy 57, 31-38

Hiroyoshi, N., Hirota, M., Hirajima, T., Tsunekawa, M., 2001. Enhancement of chalcopyrite leaching by ferrous ions in acidic ferric sulfate solutions. Hydrometallurgy $60,185-197$

Johnson, D.B., 1998. Biodiversity and ecology of acidophilic microorganisms. FEMS microbiology ecology 27, 307-317

Johnson, D.B., Joulian, C., d'Hugues, P., Hallberg, K., 2008. Sulfobacillus benefaciens sp. nov., an acidophilic facultative anaerobic Firmicute isolated from mineral bioleaching operations. Extremophiles 12, 789-798

Klauber, C., 2008. A critical review of the surface chemistry of acidic ferric sulphate dissolution of chalcopyrite with regards to hindered dissolution. International journal of mineral processing $86,1-17$

Leahy, M.J., Davidson, M.R., Schwarz, M.P., 2007. A model for heap bioleaching of chalcocite with heat balance: Mesophiles and moderate thermophiles. Hydrometallurgy $85(1), 24-41$

Morin, D., d'Hugues, P., 2007. Bioleaching of a cobalt-containing pyrite in stirred reactors: a case study from laboratory scale to industrial application. In: Rawlings, D.E., Johnson, D.B., (Eds.), Biomining. Springer, Heidelberg, pp. 35-56

Okibe, N., Gericke, M., Hallberg, K.B., Johnson, D.B., 2003. Enumeration and characterization of acidophilic microorganisms isolated from a pilot plant stirred-tank bioleaching operation. Applied and Environmental Microbiology 69, 1936 - 1943. 
Pinches, A., Gericke, M., Van Rooyen, J.V., 2000. A method of operating a bioleach process with control of redox potential. Patent WO 01/31072 A1

Pradhan, N., Nathsarma, K.C., Rao, K.S., Sukla, L.B., Mishra, B.K., 2008. Heap bioleaching of chalcopyrite: A review. Minerals engineering 21, 355-365

Rawlings, D.E., Dew, D., du Plessis C., 2003. Biomineralization of metal-containing ores and concentrates. Trends in biotechnology $21,38-44$

Rawlings, D.E., 2005. Characteristics and adaptability of iron- and sulfur-oxidizing microorganisms used for the recovery of metals from minerals and their concentrates. Microbial cell factories 4, 13

Rodriguez, Y., Ballester, A., Blazquez, M.L., Gonzalez, F., Munoz, J.A. 2003. New information on the pyrite bioleaching mechanism at low and high temperature. Hydrometallurgy 71, 37-46

Sandström, A., Shchukarev, A., Paul, J., 2005. XPS characterisation of chalcopyrite chemically and bio-leached at high and low redox potential. Minerals Engineering 18 (5), $505-515$

Third, K.A., Cord-Ruwisch, R., Watling, H.R., 2002. Control of the redox potential by oxygen limitation improves bacterial leaching of chalcopyrite. Biotechnology and Bioengineering 78, 433-441.

Tshilombo, A.F., Petersen, J., Dixon, D.G., 2002. The influence of applied potentials and temperature on the electrochemical response of chalcopyrite during bacterial leaching. Minerals Engineering 15 (11), 809-813

Van Aswegen, P.C., Van Niekerk, J., Olivier, W., 2007. The BIOX process for the treatment of refractory gold concentrates. In: Rawlings, D.E., Johnson, D.B., (Eds.), Biomining. Springer, Heidelberg, pp. 1-34 
Watling, H.R., 2006. The bioleaching of sulphide minerals with emphasis on copper sulphides - A review. Hydrometallurgy 84, 81-108.

Yajie, L., Okibe, N., Johnson, D.B., 2007. Effect of temperature on bioleaching of chalcopyrite concentrates containing high concentrations of silver: opposite rules apply. In: Schippers, A., Sand, W., Glombitza, F., Willscher, S. (Eds.), Proceedings of IBS2007, Frankfurt am Main, Germany, September 2-5, 2007. Biohydrometallurgy Advanced Materials Research 20-21, 30-33 


\section{Table captions}

Table 1. Main operating conditions of the continuous bioleaching unit

\begin{tabular}{llllll}
\hline $\begin{array}{l}\text { Configuration } \\
\text { concentration (\%) }\end{array}$ & $\begin{array}{l}\text { Solid } \\
\text { Tank }\end{array}$ & $\begin{array}{l}\text { Residence } \\
\text { time (days) }\end{array}$ & $\begin{array}{l}\text { Agitation } \\
\text { rate (rpm) }\end{array}$ & $\begin{array}{l}\text { Aeration } \\
\text { rate }\left(\mathrm{L} \mathrm{h}^{-1}\right)\end{array}$ \\
\hline \multirow{3}{*}{10} & $\mathrm{R} 1$ & 3.3 & 350 & 2000 \\
& & $\mathrm{R} 2$ & 1.6 & 390 & 900 \\
& & $\mathrm{R} 3$ & 1.6 & 390 & 700 \\
$2 \mathrm{a}$ & \multirow{2}{*}{15} & $\mathrm{R} 1$ & 2.1 & 390 & 500 \\
& & $\mathrm{R} 2$ & 2.2 & 390 & 400 \\
& & $\mathrm{R} 3$ & 2.3 & 390 & 400 \\
$2 \mathrm{~b}$ & 15 & $\mathrm{R} 1$ & 2.1 & 390 & 500 \\
& & $\mathrm{R} 2$ & 2.2 & 250 & 100 \\
& & $\mathrm{R} 3$ & 2.3 & 250 & 100 \\
\hline
\end{tabular}

Table 2. Economic analysis of the concentrate bioprocessing. Comparison between a process taking into account copper and silver production or copper production only.

\begin{tabular}{lll}
\hline & $\begin{array}{l}\text { Copper and silver } \\
\text { production }\end{array}$ & $\begin{array}{l}\text { Copper } \\
\text { production }\end{array}$ \\
\hline Total investment cost (million $€$ ) & 457 & 392 \\
Operating cost (million $€ /$ year) & 117 & 113 \\
Sales (million $€ /$ year) & 197 & 149 \\
Payback (years) & 5.7 & 10.9 \\
\hline
\end{tabular}




\section{Figure captions}

Figure 1. Batch bioleaching in stirred reactors with Bioshale-BRGM consortium. Copper concentration vs. time

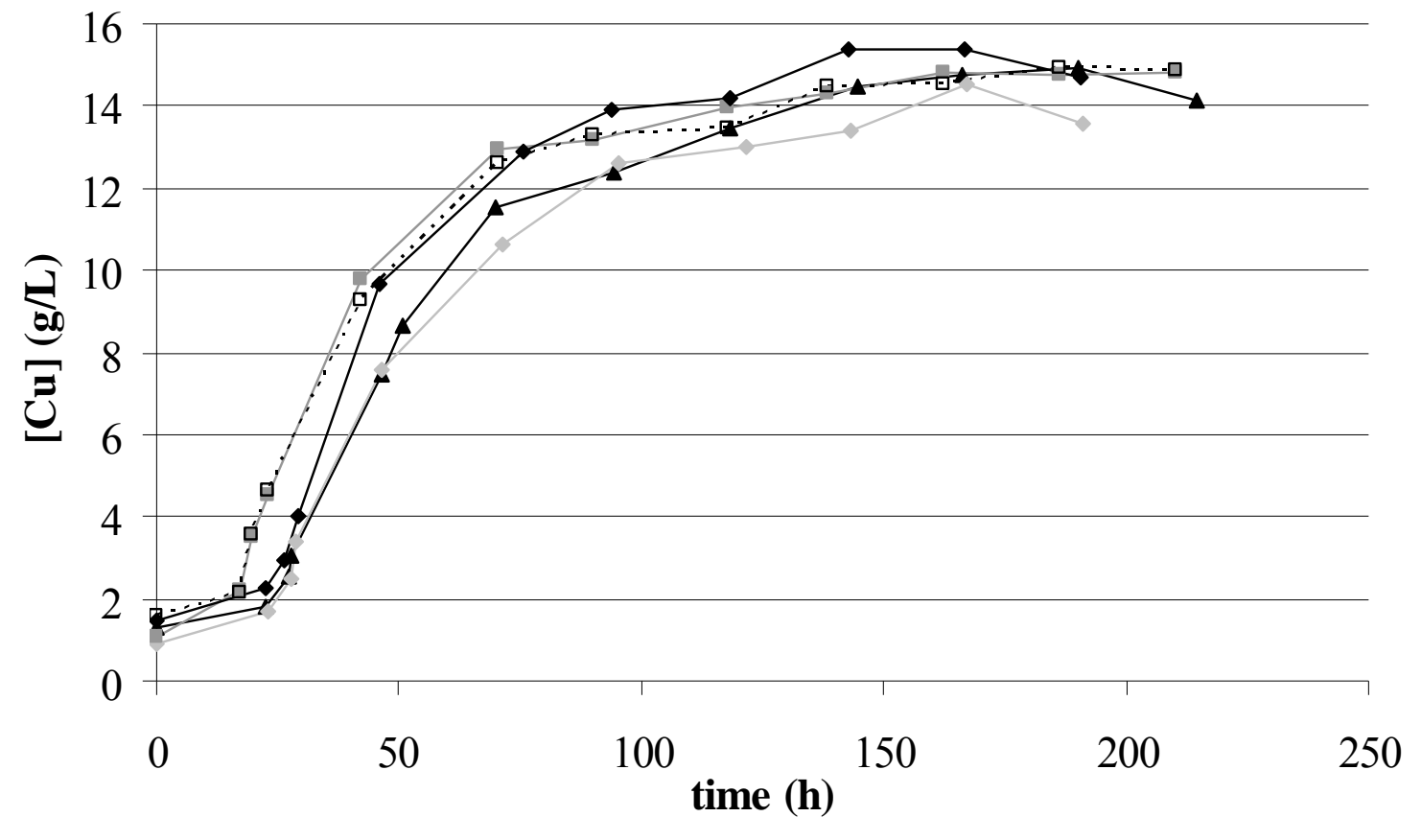

Figure 2. Influence of solids concentration in the feed and key operating parameters on copper dissolution vs. residence time. 


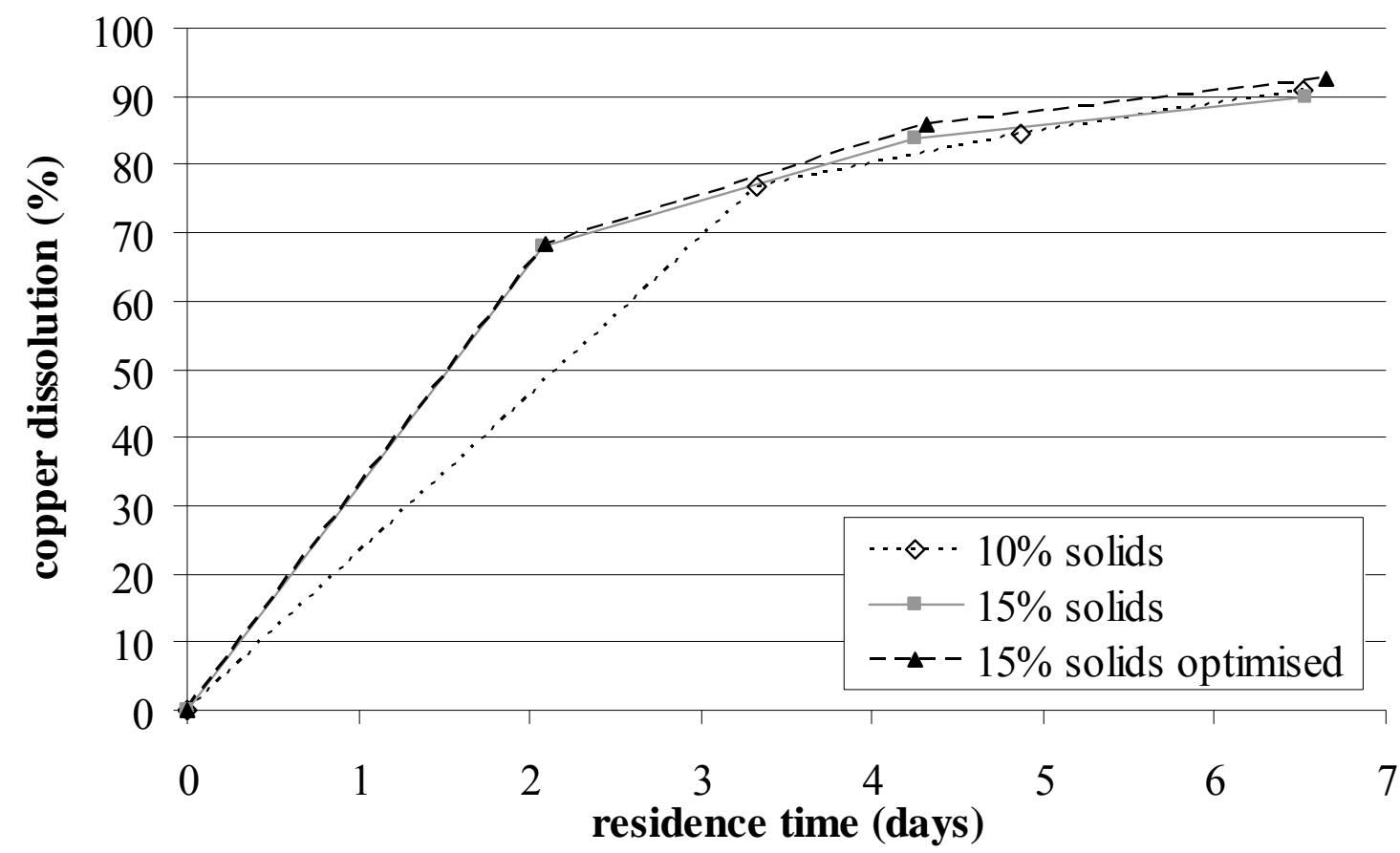

Figure 3. Evolution of the electrochemical potential in the continuous pilot operation at $15 \%$ solids. Influence of the decrease of aeration/agitation rates.

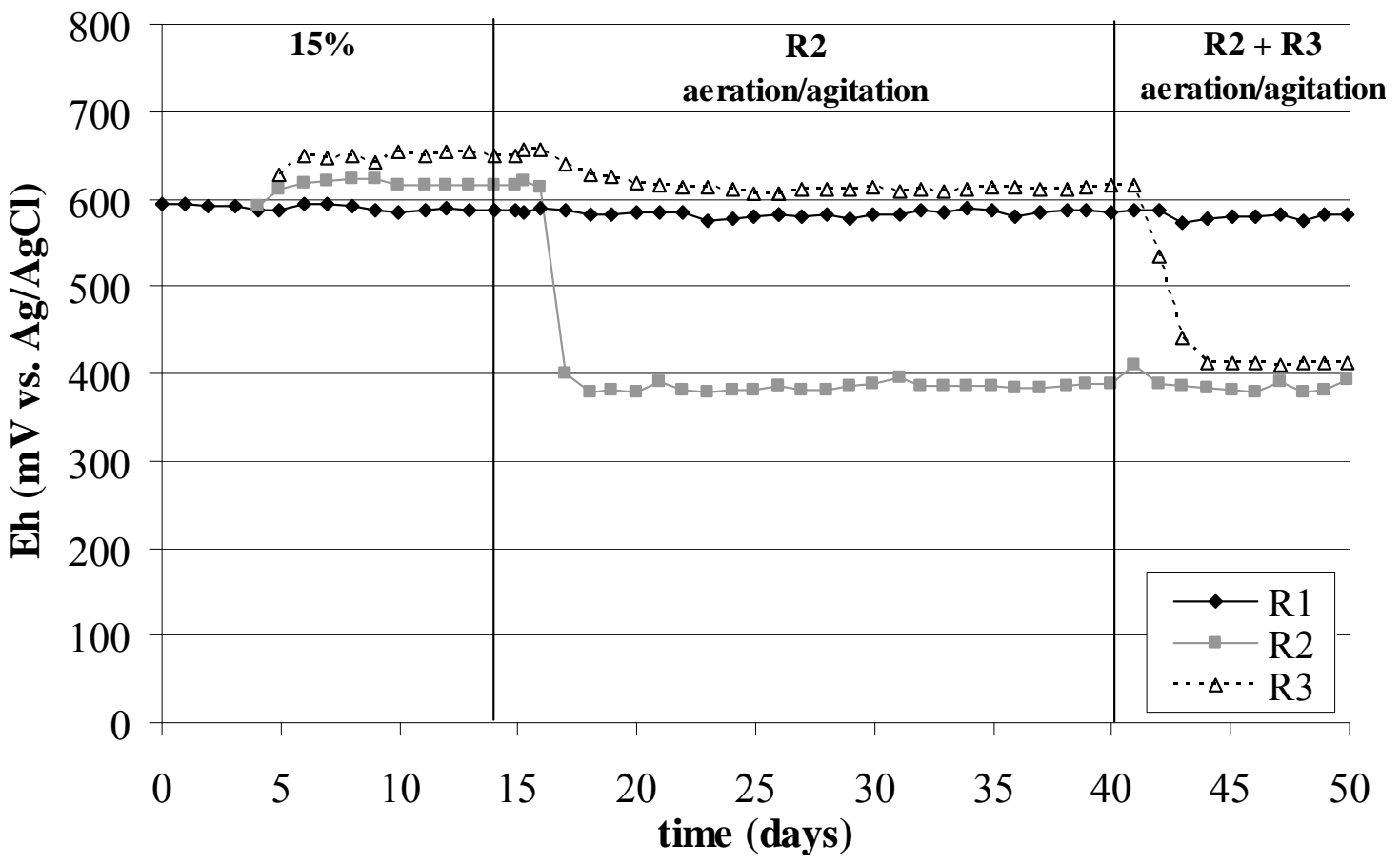


Figure 4. Bacterial community structure determined from CE-SSCP fingerprints in the three reactors of the continuous unit after 15 days of operation at $15 \%$ solids, configuration $2 \mathrm{a}$ (a.) and at the end of operation with less agitation/aeration in R2 and R3, configuration $2 b(b$.$) .$
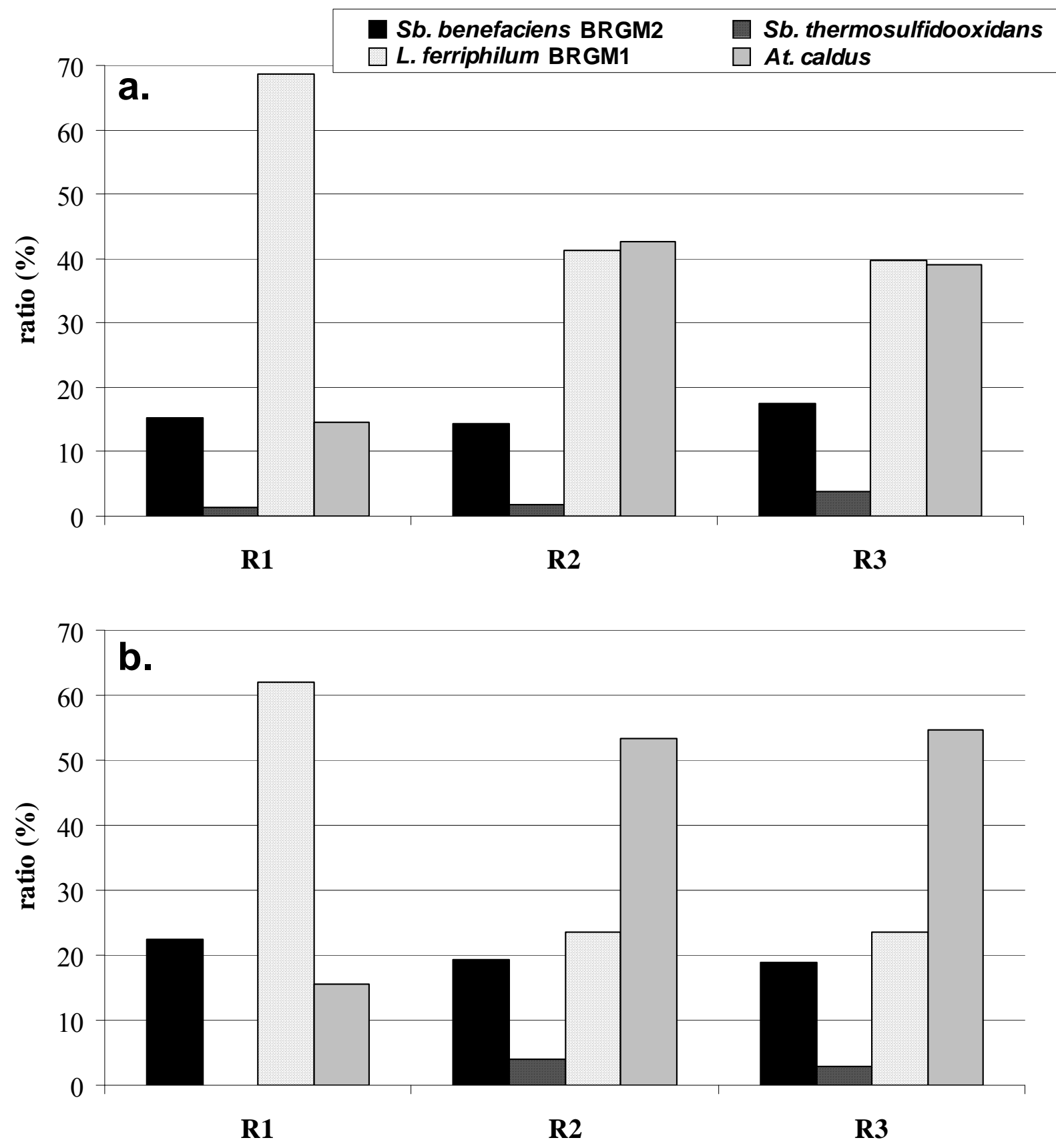
Figure 5. Comparison of the copper sulphides composition of the concentrate (a.) and bioleach residue in the reactors of the continuous operation (b., c. and d. for reactors R1, $\mathrm{R} 2$ and R3, respectively) at 15\% solids in optimised conditions (configuration $2 \mathrm{~b}$ ).

a.

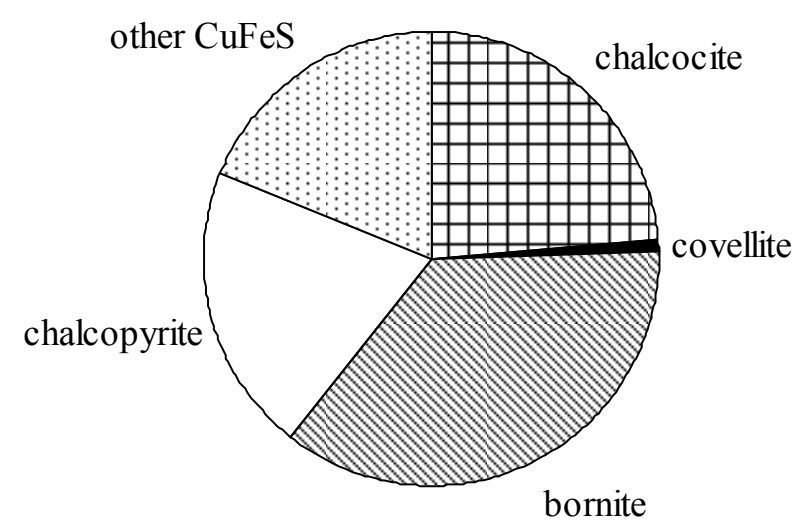

c.

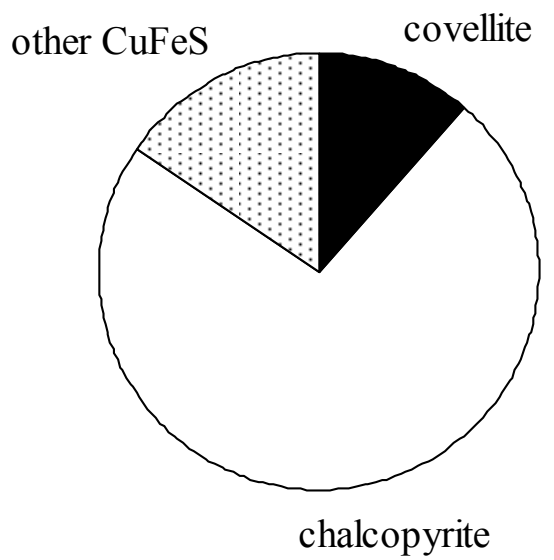

b.

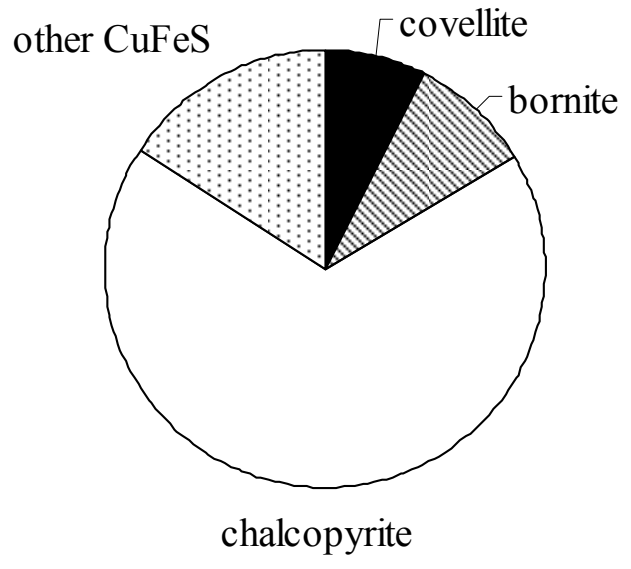

d.

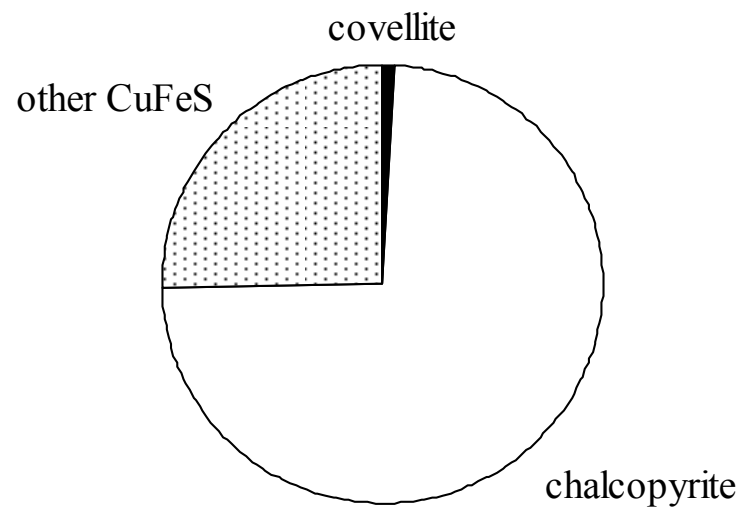

Figure 6. Block diagram of the simplified flowsheet of the concentrate bioprocessing. 


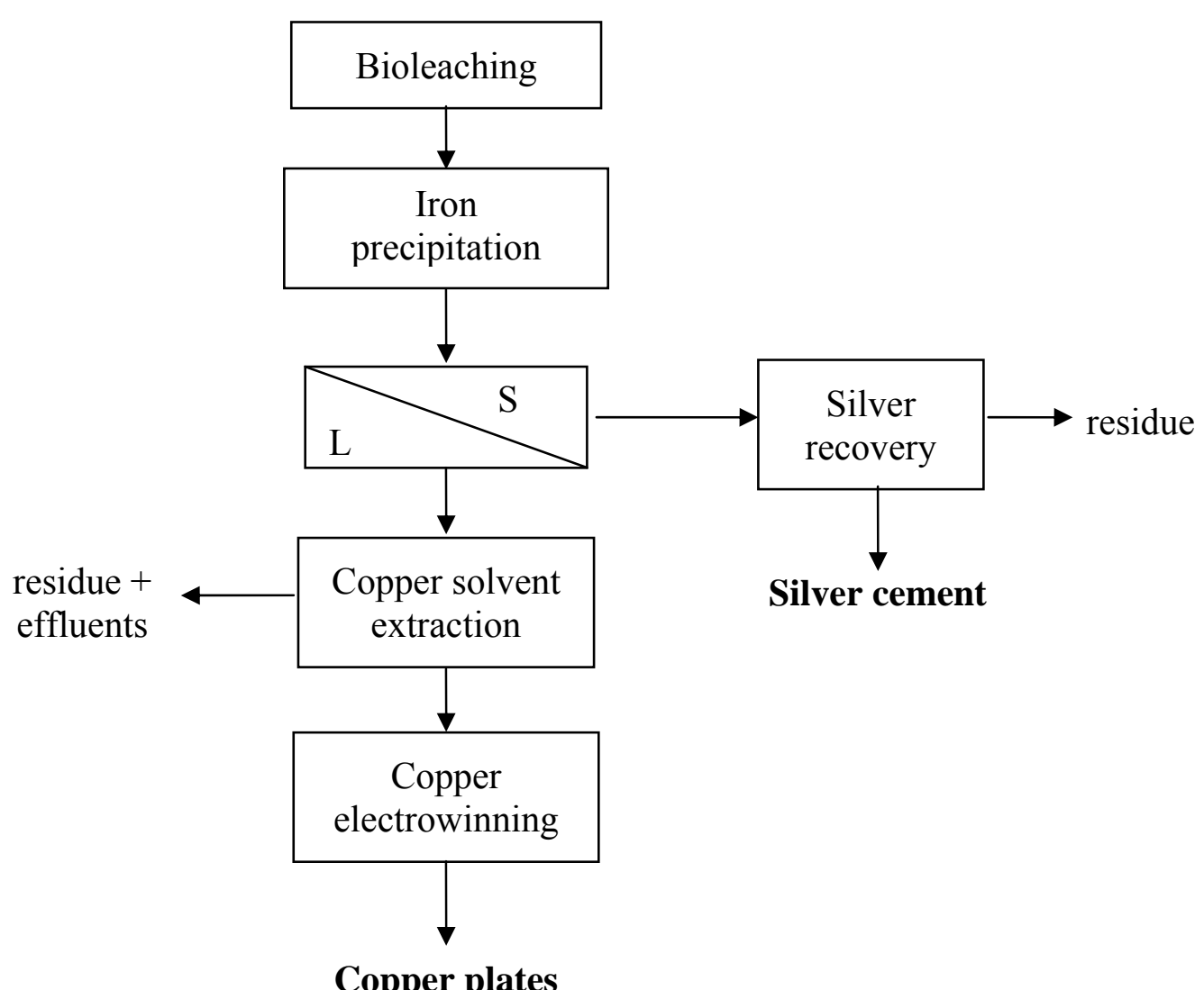

